\title{
Potentials of Liquefied CCB Treated Waste Wood for Wood Preservation
}

\section{Mogućnosti uporabe utekućenoga otpadnog drva obrađenoga krom-bakar-boratom za zaštitu drva}

\author{
Original scientific paper • Izvorni znanstveni rad \\ Received-prispjelo: 7. 3. 2011. \\ Accepted-prihvaćeno: 14. 7. 2011. \\ UDK: $630 * 841.112 ; 630 * 841.2 ; 630 * 841.3$ \\ doi:10.5552/drind.2011.1110
}

\begin{abstract}
Recovered wood is frequently contaminated with biocides and therefore its use is limited. Even more, wood, impregnated with classical chromated copper arsenate (CCA) preservatives is classified as a hazardous waste, therefore solutions for reuse or recovery of this material are sought. One of the options, discussed in this paper is liquefaction and further applications of liquefied wood containing biocide remainings. In order to elucidate this possibilty, spruce and beech wood was impregnated with liquefied CCB treated and untreaded spruce wood of various concentrations and exposed to wood decay fungi according to the EN 113 procedure. In paralel, the leaching experiments (ENV 1250-2) were performed as well. The results do not clearly show that liquefied wood is bio-inactive. In most cases the mass loss by fungal attack is decreased compared to the untreated controls. On the other hand, copper leaching from spruce wood, impregnated with the liquefied CCB treated wood was significantly reduced. Thus, there are indications that the liquefied wood could be utilized as a binding agent for inorganic biocides.
\end{abstract}

Keywords: liquefied wood, wood decay fungi, wood preservation, leaching, CCB, copper

\begin{abstract}
SAŽETAK - Prikupljeno uporabljeno drvo često je onečišćeno biocidima te je njegova ponovna uporaba ograničena. Osim toga, drvo impregnirano klasičnim krom-bakar-arsenat (CCA) zaštitnim sredstvima klasificirano je kao opasni otpad te je nužno pronaći rješenje za ponovnu uporabu ili sanaciju tako onečišćenog drva. Jedna od mogućnosti, prezentirana u ovome radu, jest utekućenje drva i daljnja primjena tako utekućenog drva koje sadržava preostale biocide. Radi razjašnjenja te mogućnosti, smrekovo i bukovo drvo impregnirano je utekućenom nezaštićenom smrekovinom i utekućenom smrekovinom zaštićenom krom-bakar-boratom različitih koncentracija. Tako obrađeno drvo izloženo je djelovanju gljiva, sukladno postupku opisanom u normi EN 113. Paralelno je proveden eksperiment ispiranja (ENV 1250-2). Rezultati istraživanja nisu jasno pokazali da utekućeno drvo nije bioaktivno. U većini je slučajeva gubitak mase zbog djelovanja gljiva smanjen u usporedbi s neobrađenim kontrolnim uzorcima. Osim toga, ispiranje bakra iz smrekovine impregnirane utekućenim drvom zaštićenim CCB-om znatno je smanjeno. Prema tomu, postoje znakovi da se utekućeno drvo može upotrijebiti kao vezivno sredstvo za anorganske biocide.
\end{abstract}

Ključne riječi: utekućeno drvo, gljive truležnice, zaštita drva, ispiranje, CCB, bakar

\footnotetext{
Authors are assistant professor, assistants and professor at University of Ljubljana, Biotechnical Faculty, Ljubljana, Slovenia.

Autori su docent, asistenti i profesor Biotehničkog fakulteta Sveučilišta u Ljubljani, Ljubljana, Slovenija.
} 


\section{INTRODUCTION}

\section{UVOD}

Concerns about the safety and environmental impacts of impregnated recovered wood have increased in recent years and so has also research into methods to solve the handling problem of this important material. The main problem with impregnated recovered wood is that it still contains significant portions of preservatives, which were chosen due to their toxicity towards wood decay organisms. However, these preservatives are also toxic to other organisms and are thus potentially harmful to humans and to the environment (Amartey et al., 2007).

The present paper focuses on waste wood that was originally preserved with inorganic copper-based preservatives, of which CCA (chromated copper arsenate) and CCB (chromated copper borate) are the most abundant. CCA treated wood is classified as hazardous wood waste at the end of its service life in some member states of the EU and is subject to stringent requirements. In other member states it is classified as nonhazardous and therefore subject to much less stringent requirements (Helsen and Van den Bulck, 2005).

Even though the use of CCA and CCB has decreased recently in several countries (due to a ban on consumer use of arsenic treated wood in the EU, the USA, and Canada), the amount of CCA treated waste wood is expected to increase drastically in several countries in the years to come, e.g. Florida, USA (SoloGabriele and Townsend, 2000) and Denmark (Affald 21, 1999). The demand for methods that ensure environmentally safe and economically feasible handling of this impregnated wood waste is huge.

Different methods for the disposal of CCA and CCB treated wood waste are currently under development or have been implemented in various countries (either in a demonstration phase or in an industrial setup). These methods include recycling and recovery of the wood, thermal destruction and remediation (e.g. bioremediation, extraction, etc.). The different methods of dealing with this treated wood waste were outlined by Helsen and Van den Bulck (2005). Reuse involves the use of wood in new constructions e.g. land piling and fences whereas recycling involves the production of wood based composites. However, in several countries, reuse and recycling of impregnated wood is forbidden. Nevertheless, at some point, the wood ends up as waste wood even though it has been reused (Amartey et al., 2007).

Liquefaction of treated wood and its possible uses for wood protection are outlined herein. Liquefaction is one of the techniques that can convert wood biomass into useful liquid materials (Tatsuhiko and Hirokuni, 2001). Shiraishi and Hse (2001) recycled creosote-treated southern pine by liquefaction in phenol and were able to prepare novolac resin from the liquefied creosote treated wood. They discovered that this resin is suitable for production of adhesives for plywood. Lin and Hse (2005) reported that more than
$90 \%$ of toxic metals $(\mathrm{Cu}, \mathrm{Cr}$, or $\mathrm{As})$ can be removed from liquefied CCA-treated wood by precipitation. However, up to our best knowledge, there are no literature data on a potential (re)use of the liquefied CCB treated wood as a preservative solution. The aim of the study presented herein was to clarify the fungicidal properties and leaching resistance of liquefied CCB containing wood.

\section{MATERIAL AND METHODS}

\section{MATERIJAL I METODE}

Two types of Norway spruce (Picea abies Karst.) wood were used for liquefaction: uncontaminated spruce wood sawdust and Norway spruce wood impregnated with a commercial preservative $\mathrm{CCB}$ solution, consisting of $34.0 \% \mathrm{CuSO}_{4} \times 5 \mathrm{H}_{2} \mathrm{O}, 37.3 \% \mathrm{~K}_{2} \mathrm{Cr}_{2} \mathrm{O}_{7}$ and $28.7 \% \mathrm{H}_{3} \mathrm{BO}_{3}$ (Silvanol, Silvaprodukt, Ljubljana, Slovenia). Norway spruce wood sawdust was soaked to the aqueous solution of CCB for three days in order to achieve uniform distribution and sufficient absorption. Afterwards, impregnated wood was oven dried at $60{ }^{\circ} \mathrm{C}$ for 7 days to ensure complete reduction of chromium. Retention of the CCB in treated wood was $4 \mathrm{~kg} \mathrm{~m}^{-3}$, as required for the most frequent use class 3 applications (outdoor) (Willeitner, 2001). The liquefaction was carried out in a $1000 \mathrm{~mL}$ reactor equipped with a stirrer and a cooler. The spruce wood sawdust was fractionated using a $0.24 \mathrm{~mm}$ sieve and oven dried $\left(24 \mathrm{~h}, 103{ }^{\circ} \mathrm{C}\right)$ prior to liquefaction. The reaction mixture was prepared with $150 \mathrm{~g}$ of uncontaminated spruce wood sawdust or spruce wood sawdust impregnated with the commercial preservative solution - CCB, $450 \mathrm{~g}$ of ethylene glycol and $13.5 \mathrm{~g}$ of sulphuric acid. The mixture was then transferred into a glass reactor and the reactor was immersed in an oil bath preheated to $180^{\circ} \mathrm{C}$ to start the reaction. The reaction time was set to $90 \mathrm{~min}$. After elapsed time, the liquefied wood was used for impregnation and subsequent analysis.

The reaction between ethylene glycol and sulphuric acid without wood was performed as well, in order to determine the fungicidal effect of the "liquefaction" product without wood (450 $\mathrm{g}$ of ethylene glycol and $13.5 \mathrm{~g}$ of sulphuric acid, $90 \mathrm{~min}$ ). Prior to impregnation of beech and Norway spruce wood specimens, the liquefied wood was diluted with water, because the undiluted liquefied wood was too viscous to be used for impregnation (dilution ratios are presented in Table 1). The diluted liquefied wood was homogenized with a disperser ( T 25 digital ultra-turrax, Ika) for $10 \mathrm{~min}$. Concentration of copper in impregnated wood and in liquefied CCB treated wood was determined with X-ray fluorescence spectroscopy (Oxford instruments, Twin-x). The measurements were performed with PIN detector $(U=26 \mathrm{kV}, I=112 \mu \mathrm{A}, t=360 \mathrm{~s})$ on three parallel specimens.

The samples for the tests with fungi were made of beech (Fagus sylvatica L.) and Norway spruce (Picea abies Karst.) wood. The dimensions $(1.5 \mathrm{~cm} \times 2.5$ $\mathrm{cm} \times 5.0 \mathrm{~cm})$ and orientation met the requirements of 
the standards EN 113 (2004) and ENV 1250-2 (2004). The samples were vacuum-pressure impregnated $(20$ min vacuum -0.9 bar; 2 h 9 bar, 10 min vacuum -0.8 bar) (impregnation chamber Kambič) with 11 different preservative solutions as can be seen in Tables 1 and 2 . Uptake of preservative solutions, and retentions were determined gravimetrically. The impregnated specimens were conditioned in the first two weeks after the treatment in closed chambers, the third week in halfclosed and the fourth week in open ones, according to the recommendations of the standards ENV 1250-2 and EN 113. The control specimens exposed to wood decay fungi were left un-impregnated.

Resistance of impregnated wood against wood decay fungi was determined according to the modified EN 113 (2004) procedure. Beech wood specimens were exposed to white rot fungi (Trametes versicolor (L.:Fr.) Quél. and Hypoxylon fragiforme (Pers.) J. Kickx f.) and spruce wood specimens were exposed to brown rot ones (Gloeophyllum trabeum (Pers.) Murrill, and Antrodia vaillantii (DC.) Ryvarden). Two specimens were exposed in the same incubation jar $(\mathrm{V}=500$ $\mathrm{ml}$ ), one impregnated and the other one un-impregnated. Control specimens were also exposed in separate jars, as the virulence controls. The surface of the inoculated nutrient medium was approximately $115 \mathrm{~cm}^{2}$ large. After 16 weeks of exposure, mass losses of the decayed specimens were determined gravimetrically. The biological part of the investigation was performed on five replicate specimens.

For the leaching tests, only two series of wood specimens, impregnated with two different diluted liquefied CCB wood solutions were chosen (see the first two rows in Table 2). For comparison (the third row in Table 2), an aqueous solution containing the same amount of copper as in the three times diluted liquefied wood was included as well $\left(c_{\mathrm{Cu}}=170 \mathrm{ppm}\right)$. Prior to impregnation, axial surfaces of the specimens were end sealed with an epoxy coating (Epolor, Color). In order to further speed up the experiment, the following two modifications of the ENV 1250-2 standard procedure were done: instead of five, three specimens were positioned in the same vessels and water mixing was achieved with shaking by the non-rotatory shaker (Kambič) device instead of using magnetic stirrer. To obtain three parallel leaching test data sets, nine specimens per solution/concentration/treatment were put in three separate vessels (three specimens per vessel). Afterwards, the samples in the vessels were positioned with weights. $300 \mathrm{~g}$ of deionized water was added per vessel and the vessels with its contents were shaken with a frequency of $60 \mathrm{~min}^{-1}$. Water was replaced for six times in four subsequent days, as prescribed by the standard. Leachates from the same vessel were collected and aggregated. Afterwards, atomic absorption spectroscopy (Varian SpectrAA Duo FS240) analysis of the leachates was performed. Percentages of the leached copper were calculated from the amount of retained copper, determined gravimetrically and the amount of copper in the collected leachates was established.

\section{RESULTS AND DISCUSSION}

\section{REZULTATI I RASPRAVA}

The impregnation process resulted in rather high uptakes of preservative solutions. The average uptakes of preservative solutions were about $650 \mathrm{~kg} \cdot \mathrm{m}^{-3}$. Wood species and composition of preservative solution did not have significant influence on the uptake. This is rather surprising, as the uptake of a viscous solution is usually higher with beech specimens than the uptake with spruce specimens (Lesar and Humar, 2010). Presumably, there are two main reasons for comparable uptakes of beech and spruce wood specimens: firstly, the specimens were rather small, with rather high portions of axial surfaces and secondly, the liquefied wood contained ethylene glycol that causes wood swelling (Mantanis et al. 1994), which enables penetration of larger molecules of liquefied wood to less permeable wood species (such as spruce).

Mass loss of the control specimens varied between $15.9 \%$ and $36.3 \%$. The highest mass loss was measured with beech wood exposed to $H$. fragiforme and the lowest one with spruce wood exposed to $A$. vaillantii (Table 1). It should be considered that this mass loss is rather low, but this is in line with our previous results (e.g. Humar and Lesar, 2008). This fungal strain was chosen as it is extremely tolerant to copper and some other biocides, and with copper treated specimens mass losses are generally higher than mass losses of control specimens (Humar and Lesar, 2008), which can be clearly seen from our results as well.

Polyols are frequently used for liquefaction of wood. The results of Budija et al. (2009) clearly indicated that liquefied wood contains considerable portions of polyol. Thus, the influence of the reaction product between pure ethylene glycol and sulphuric acid, without wood, on fungal growth was of a particular interest as well. The results presented in Table 1 clearly show that the reaction product of ethylene glycol and $\mathrm{H}_{2} \mathrm{SO}_{4}$ reduced decay, but not enough to fulfill the requirements of the EN 113 standard. According to EN 113 , wood protection provided by a wood preservative at a given concentration is regarded as adequate if the mean mass loss of treated specimens is less than $3 \%$ of their initial dry mass. For example, mass losses of the control specimens exposed to G. trabeum (33.8\%) were approximately three times higher than mass losses of spruce wood specimens, impregnated with the aqueous solution of the product formed during the reaction between ethylene glycol and $\mathrm{H}_{2} \mathrm{SO}_{4}(13.3 \%)$. But this value is still more than four times higher than prescribed by the EN 113 standard for effective preservatives. Similar influence of the glycol - sulphuric acid reaction product was determined with other specimens, exposed to wood decay fungi, with an exemption of $A$. vaillantii. Mass loss of the specimens, impregnated with the ethylene glycol - $\mathrm{H}_{2} \mathrm{SO}_{4}$ product was in this case only two percentage points lower than the mass loss of the control spruce wood specimens (Table 1).

Despite the fact that more than $100 \mathrm{~kg} \cdot \mathrm{m}^{-3}$ of the dry liquefied wood remained in the impregnated wood 
Table 1 Influence of impregnation with various aqueous solutions based on liquefied (liq.) wood and liquefied CCB treated wood on mass losses of spruce or beech wood specimens after 16 weeks of exposure to wood decay fungi (standard deviations are given in brackets)

Tablica 1. Utjecaj impregnacije različitim vodenim otopinama na bazi utekućenog drva i utekućenoga drvnog otpada zaštićenoga CCB-om na gubitak mase uzoraka od smrekovine i bukovine nakon 16 tjedana izlaganja gljivama truležnicama (standardne devijacije dane su u zagradama)

\begin{tabular}{|c|c|c|c|c|c|}
\hline \multirow{3}{*}{$\begin{array}{l}\text { Impregnation solution } \\
\text { Otopina za impregnaciju } \\
\text { water : liquefied wood mass ratio } \\
\text { maseni omjer voda : utekućeno drvo }\end{array}$} & \multirow{3}{*}{$\begin{array}{c}\text { Retention } \\
\text { Retencija } \\
\mathrm{kg} / \mathrm{m}^{3}\end{array}$} & \multicolumn{4}{|c|}{ Wood decay fungi* / Gljiva truležnica } \\
\hline & & A. vaillantii & G. trabeum & T. versicolor & H. fragiforme \\
\hline & & \multicolumn{4}{|c|}{ Mass loss, \% / Gubitak mase, \% } \\
\hline 3:1 liq. wood / 3: 1 utekućeno drvo & $89.5(12.1)$ & $19.2(2.6)$ & $19.1(2.0)$ & $22.8(1.7)$ & $21.7(3.1)$ \\
\hline 9:1 liq. wood / 9: 1 utekućeno drvo & $44.0(8.5)$ & $14.9(1.1)$ & $15.3(2.4)$ & $17.4(2.4)$ & $15.7(3.3)$ \\
\hline $27: 1$ liq. wood / 27: 1 utekućeno drvo & $14.8(2.5)$ & $9.4(0.3)$ & $25.1(3.3)$ & $21.9(3.5)$ & $23.4(1.1)$ \\
\hline $50: 1$ liq. wood / 50: 1 utekućeno drvo & $8.2(1.6)$ & $13.0(1.7)$ & $28.5(3.2)$ & $18.8(3.4)$ & $26.1(1.8)$ \\
\hline 100: 1 liq. wood / 100: 1 utekućeno drvo & $4.5(1.2)$ & $12.4(1.0)$ & $31.7(3.4)$ & $20.7(2.9)$ & $27.3(3.5)$ \\
\hline $\begin{array}{l}3: 1 \text { liq. CCB treated wood } \\
3: 1 \text { utekućeno drvo zaštićeno CCB-om }\end{array}$ & $112.2(11.2)$ & $25.9(1.5)$ & $21.1(1.9)$ & $20.8(2.3)$ & $19.4(0.8)$ \\
\hline $\begin{array}{l}9: 1 \text { liq. CCB treated wood } \\
9: 1 \text { utekućeno drvo zaštićeno } C C B \text {-om }\end{array}$ & $44.9(3.2)$ & $14.6(2.0)$ & $17.4(3.2)$ & $14.4(2.4)$ & $15.1(3.7)$ \\
\hline $\begin{array}{l}27: 1 \text { liq. CCB treated wood } \\
27: 1 \text { utekućeno drvo zaštićeno CCB-om }\end{array}$ & $14.8(1.7)$ & $10.5(2.4)$ & $22.2(3.3)$ & $25.0(1.8)$ & $27.1(1.3)$ \\
\hline $\begin{array}{l}50: 1 \text { liq. CCB treated wood } \\
50: 1 \text { utekućeno drvo zaštićeno CCB-om }\end{array}$ & $11.7(2.7)$ & $11.0(1.8)$ & $22.4(3.0)$ & $17.9(2.1)$ & $25.0(3.3)$ \\
\hline $\begin{array}{l}100: 1 \text { liq. CCB treated wood } \\
100: 1 \text { utekućeno drvo zaštićeno CCB-om }\end{array}$ & $7.0(4.7)$ & $11.9(1.2)$ & $25.1(1.8)$ & $15.0(1.9)$ & $26.0(2.1)$ \\
\hline $\begin{array}{l}3: 1 \text { ethylene glycol }+\mathrm{H}_{2} \mathrm{SO} 4 \\
3: 1 \text { etilen glikol }+\mathrm{H}_{2} \mathrm{SO} 4\end{array}$ & $47.7(8.0)$ & $12.6(1.7)$ & $13.3(1.7)$ & $14.2(1.9)$ & $14.4(0.8)$ \\
\hline Control / kontrolni uzorak & 1 & $15.9(1.5)$ & $33.8(3.2)$ & $26.7(1.8)$ & $36.3(2.6)$ \\
\hline
\end{tabular}

*The A. vailantii and G. trabeum tests were performed with spruce wood specimens and the T. versicolor and $H$. fragiforme tests with beech wood specimens. / Gljive A. vailantii i G. trabeum primijenjene su za uzorke od smrekovine, a T. versicolor i H. fragiforme za uzorke od bukovine.

after impregnation (Table 1), it did not have a major influence on fungal decay. In general, mass losses of the specimens, impregnated with the liquefied wood were higher than mass losses of the specimens impregnated with the ethylene glycol - $\mathrm{H}_{2} \mathrm{SO}_{4}$ reaction product only. Even more, mass losses of the specimens impregnated with liquefied wood and exposed to $A n$ trodia vaillantii were even higher than mass losses of control specimens. Similar results were obtained with specimens impregnated with other combinations of liquefied wood. This result indicates that liquefied wood did not have significant fungicidal effect, and therefore cannot be utilized for preservation in a current form. This is in line with the results of Alfredsen et al. (2004). They have screened four different tall oil derivates. The derivatives exhibited some fungicidal properties in agar screening test, but none of them was proven as a fungicide during mini block testing (agar block test).

It was expected that the liquefied CCB containing wood could perform better than the pure liquefied wood, due to the remained biocides (copper and boron). The concentration of copper in the three times diluted liquefied CCB treated wood ( $3: 1$ liq. CCB treated wood) was $170 \mathrm{ppm}$. Therefore, the results of the fungicidal test were unexpected. Wood, impregnated with the liquefied CCB containing wood, exhibited the same weak resistance against wood decay fungi as wood impregnated with the pure liquefied spruce wood, despite the fact that there was approximately $0.12 \mathrm{~kg} \cdot \mathrm{m}^{-3}$ of copper in wood impregnated with the highest solution of the liquefied CCB treated wood. It has been reported (Humar and Lesar, 2008) that this retention is sufficient to protect wood at least against copper sensitive fungi like G. trabeum and $T$. versicolor. There could be two reasons for low efficacy of wood impregnated with the liquefied CCB treated wood. Firstly, copper in liquefied wood might be in insoluble or in a less fungicidal form, which decreases its efficacy. And secondly, liquefied wood is acidic. Average $\mathrm{pH}$ of liquefied wood is around 1 (Budija, 2010). It is well known that copper is considerably less fungitoxic in an acid environment than in a neutral one (Humar et al., 2005).

In the second part of the research we were interested in the leaching of the active ingredients from wood, impregnated with the liquefied CCB containing wood. This question was of a general interest, as one of the issues related to copper based preservatives is how to achieve sufficient copper fixation in wood. Between $40 \%$ and $60 \%$ of copper is leached from wood impregnated with the aqueous solution of copper without liquefied wood (Richardson, 1997). Similar leaching ratios were also determined with spruce and beech wood specimens impregnated with copper(II) sulphate solution in our experiment (Table 2).

Surprisingly, considerably lower leaching rates were determined from wood impregnated with the liquefied $\mathrm{CCB}$ treated wood. The leaching rates were particularly low with spruce wood specimens. For in- 
Table 2 Copper leaching from wood specimens impregnated with liquefied CCB impregnated wood determined according to the ENV 1250-2 procedure

Tablica 2. Ispiranje bakra iz uzoraka drva imregniranih utekućenim drvom zaštićenim CCB-om, određeno prema postupku ENV 1250-2

\begin{tabular}{|l|l|c|}
\hline Impregnation solution / Otopina za impregnaciju & \multicolumn{1}{|c|}{$\begin{array}{c}\text { Wood species } \\
\text { water : liquefied wood mass ratio / maseni omjer voda: utekućeno drvo }\end{array}$} & $\begin{array}{c}\text { Leached Cu, \% } \\
\text { Isprani bakar, \% }\end{array}$ \\
\hline $3: 1$ liq. CCB treated wood & beech / bukovina & $17.7(2.1)$ \\
\cline { 2 - 3 } $3: 1$ utekućeno drvo zaštićeno CCB-om & spruce / smrekovina & $4.2(0.6)$ \\
\hline 9: 1 liq. CCB treated wood & beech / bukovina & $20.1(1.7)$ \\
\cline { 2 - 3 } 9:1 utekućeno drvo zaštićeno CCB-om & spruce / smrekovina & $5.4(0.3)$ \\
\hline * aqueous solution of copper(II) sulfate & beech / bukovina & $57.8(2.9)$ \\
\cline { 2 - 3 } vodena otopina bakar(II)sulfata & spruce / smrekovina & $56.7(2.4)$ \\
\hline
\end{tabular}

*For comparison, specimens were treated with the aqueous solution of copper(II) sulfate of the same concentration as in liquefied CCB treated wood (of the $3: 1$ dilution ratio). Standard deviations are given in the parenthesis. / Za usporedbu, uzorci su obrađeni vodenom otopinom bakar(II)sulfata jednake koncentracije kao i uzorci obrađeni utekućenim drvom zaštićenim CCB-om (omjer razrjeđenja 3:1). Standardne devijacije dane su u zagradama.

stance, from spruce wood blocks, impregnated with the liquefied CCB treated wood, between $4.2 \%$ and $5.4 \%$ of retained copper was leached. This is considerably lower than reported for copper(II) sulfate treated wood. Furthermore, these leaching rates are comparable to the leaching rates determined with copper-ethanolamine treated wood (Zhang and Kamdem, 2000). However, leaching from beech wood, impregnated with the liquefied CCB treated wood, was approximately four times higher (Table 2). This might be somehow related to the fact that liquefied CCB treated wood was made of spruce wood. Similar results were observed with the leached beech and spruce wood blocks, impregnated with the aqueous solutions of boric acid and liquefied spruce wood (Lesar et al., 2011). This presumption needs to be addressed in future studies.

Normally, the observed low leaching rates of copper from wood, impregnated with the liquefied wood containing $\mathrm{CCB}$, can be considered useless in the context of disappointingly low antifungal resistance of wood, impregnated with the CCB liquefied wood. However, low copper leaching supports the assumed reason for low efficacy: copper in combination with the liquefied wood assumably formed less soluble or insoluble forms. A possible application of the recovered CCB contaminated wood could be in the preparation of new wood protecting copper based solutions. Careful tuning of the ratio between liquefied wood and copper in such solutions could retain some copper efficacy on one side and on the other side decrease its leaching. The appropriate fungicidal efficacy could be improved by the addition of a co-biocide.

\section{CONCLUSIONS}

\section{ZAKLJUČCl}

Wood, impregnated with liquefied wood did not exhibit sufficient resistance against wood decay fungi. Also the wood, impregnated with the liquefied CCB containing wood, was not effectively protected against the selected wood degrading fungi. This indicates that CCB treated liquefied wood needs to be supplemented with additional biocides to ensure sufficient protection. However, copper leaching from spruce wood, impregnated with the liquefied CCB treated wood, was signi- ficantly reduced. Thus, there are indications that the liquefied wood could be utilized as a binding agent for inorganic biocides. However, up to our best knowledge, we are not aware of studies on energy consumption during wood liquefaction processes. Potentially, wood liquefaction could be costly and economically inefficient in industrial scale. So, there is an urgent need to perform economic analyses of wood liquefaction before a decision for industrial applications of liquefied wood is made.

\section{Acknowledgments - Zahvala}

The authors would like to acknowledge the Slovenian Research Agency (ARRS) for financial support in the framework of the projects L4-0820-0481, L42144-0481 and P4-0015-0481. Technical support of Dejan Fridrih is appreciated as well.

\section{REFERENCES}

\section{LITERATURA}

1. Affald 21 1999: Regeringens affaldsplan 1998-1994. Miljø- og EnergiMinisteriet (waste 21) ISBN 87-7909-2977 (In Danish).

2. Alfredsen, G.; Flæte, P.O.; Temiz, A.; Eikenes, M.; Militz H. 2004: Screening of the efficacy of tall oils against wood decaying fungi, The International Research Group on Wood Protection, IRG/WP 04-30354

3. Amartey, S.A.; Ribeiro, A.; Humar, M.; Helsen, L.; Ottosen, L. 2007: Remediation of CCA treated wood waste. In: Gallis, C. (Eds.). Management of recovered wood : reaching a higher technical, economic and environmental standard in Europe. Thessaloniki: University studio press. Thessaloniki, pp. 117-130.

4. Budija, F. 2010: Preparation and characterisation of crosslinked coatings from liquefied poplar wood. Doc. diss. University of Ljubljana. Ljubljana, Slovenia

5. Budija, F.; Tavzes, Č.; Zupančič-Kralj, L.; Petrič, M. 2009: Self-crosslinking and film formation ability of liquefied black poplar. Bioresour. technol. 100, 3316-3323, http://dx.doi.org/10.1016/j.biortech.2009.02.004

6. EN 113 2004: Wood preservatives - Test method for determining the protective effectiveness against wood destroying basidiomycetes - Determination of the toxic values

7. ENV 1250-2 2004; Wood preservatives - Methods for measuring losses of active ingredients and other preser- 
vative ingredients from treated timber - Part 2: Laboratory method for obtaining samples for analysis to measure losses by leaching into water or synthetic sea water

8. Helsen, L.; van den Bulck. E. 2005: Review of disposal technologies for chromated copper arsenate (CCA) treated wood waste, with detailed analyses of thermochemical conversion processes. Environmental Pollution. 134, 301-314, http://dx.doi.org/10.1016/j.envpol.2004.07.025

9. Humar, M.; Lesar, B. 2008: Fungicidal properties of individual components of copper-ethanolamine-based wood preservatives. Int. biodeterior. biodegrad. 62, 46-50.

10. Humar, M.; Šentjurc, M.; Amartey, S.A.; Pohleven, F. 2005: Influence of acidification of $\mathrm{CCB}(\mathrm{Cu} / \mathrm{Cr} / \mathrm{B}) \mathrm{im}-$ pregnated wood on fungal copper tolerance. Chemosphere. $58,743-749$,

http://dx.doi.org/10.1016/j.chemosphere.2004.09.031

11. Lesar, B.; Budija, F.; Kralj, P.; Petrič, M.; Humar, M. Leaching of boron from wood impregnated with preservative solutions based on boric acid and liquefied wood. European Journal of Wood and Wood Products, February 18th 2011, http://dx.doi.org/10.1007/s00107-011-0530-6

12. Lesar, B.; Humar, M. Use of wax emulsions for improvement of wood durability and sorption properties. European Journal of Wood and Wood Products, March 19th 2010, http://dx.doi.org/10.1007/s00107-010-0425-y

13. Lin L.; Hse C.Y. 2005: Liquefaction of CCA-treated wood and elimination of metals from the solvent by precipitation. Holzforschung. 59, 285-288, http://dx.doi.org/10.1515/HF.2005.047

14. Mantanis, G.I.; Young, R.A.; Rowell, R.M. 1994: Swelling of Wood. Holzforschung. 48, 480-490, http://dx.doi.org/10.1515/hfsg.1994.48.6.480
15. Richardson, H.W. 1997: Handbook of copper compounds and applications. M. Dekker, New York, USA

16. Shiraishi, N.; Hse, C.Y. 2000: Liquefaction of the used creosote-treated wood in the presence of phenol and its application to phenolic resin. In: Wood adhesives 2000 Advances in wood adhesive formulations, pp. 259-266.

17. Solo-Gabriele, H.; Townsend, T. 2000: Florida Center for Solid and Hazardous Waste Management. Report \#00-03.

18. Tatsuhiko, Y.; Hirokuni, O. 2001: Characterization of the products resulting from ethylene glycol liquefaction of cellulose. Journal of wood science. 47, 458-464, http://dx.doi.org/10.1007/BF00767898

19. Willeitner, H. 2001 Current national approaches to defining retentions in use. COST E22. Brussels.

20. Zhang, J.; Kamdem, D.P. 2000: Interaction of copperamine with southern pine. Wood and fibre science. 32, 332-339.

\section{Corresponding address:}

Prof. MARKO PETRIČ, Ph.D.

University of Ljubljana, Biotechnical Faculty Department of Wood Science and Technology Jamnikarjeva 101

SI-1000 Ljubljana, SLOVENIA

e-mail: marko.petric@bf.uni-lj.si 